\title{
Roseospira visakhapatnamensis sp. nov. and Roseospira goensis sp. nov.
}

\author{
S. Kalyan Chakravarthy, ${ }^{1}$ T. N. R. Srinivas, ${ }^{2}$ P. Anil Kumar, ${ }^{2}$ Ch. Sasikala ${ }^{2}$ \\ and Ch. V. Ramana ${ }^{1}$ \\ ${ }^{1}$ Department of Plant Sciences, School of Life Sciences, University of Hyderabad, PO Central \\ University, Hyderabad 500 046, India \\ ${ }^{2}$ Bacterial Discovery Laboratory, Centre for Environment, Institute of Science and Technology, \\ J. N. T. University, Kukatpally, Hyderabad 500 085, India
}

Correspondence

Ch. V. Ramana

r449@sify.com

or

sasi449@yahoo.ie
The genus Roseospira comprises three species with validly published names: Roseospira mediosalina (Imhoff et al., 1998a) (originally described as 'Rhodospirillum mediosalinum'; Kompantseva \& Gorlenko, 1984), Roseospira marina and Roseospira navarrensis. Another species of the genus Roseospira, 'Roseospira thiosulfatophila', has been proposed (Guyoneaud et al., 2002) but, to date, the name has not been validly published. In this communication, we propose two novel species of the genus Roseospira.

Strain $\mathrm{JA} 131^{\mathrm{T}}$ was isolated from a water sample $[\mathrm{pH} \sim 6.8$, $30{ }^{\circ} \mathrm{C}, 2-3 \%(\mathrm{w} / \mathrm{v})$ salinity] which was collected on 25 March 2004 from the fishing harbour at Visakhapatnam, India $\left(17^{\circ} 41^{\prime} \mathrm{N} 83^{\circ} 18^{\prime} \mathrm{E}\right)$. Strain $\mathrm{JA} 135^{\mathrm{T}}$ was isolated from a sediment sample $\left[\mathrm{pH} \sim 6.8 ; 30{ }^{\circ} \mathrm{C}, 6-7 \%(\mathrm{w} / \mathrm{v})\right.$ salinity] collected on 12 February 2005 from Kurka saltern, Goa, India $\left(15^{\circ} 29^{\prime} \mathrm{N} 73^{\circ} 49^{\prime} \mathrm{E}\right)$. Original enrichments of both strains were from photolithoheterotrophic media [anaerobic, $1 \mathrm{mM} \mathrm{Na} \mathrm{Na}_{2} \mathrm{~S} .9 \mathrm{H}_{2} \mathrm{O}+0.3 \%$ (w/v) pyruvate/ malate]. Strain $\mathrm{JA} 131^{\mathrm{T}}$ was isolated from an enrichment

The GenBank/EMBL/DDBJ accession numbers for the $16 \mathrm{~S}$ rRNA gene sequences of strains $\mathrm{JA} 131^{\top}$ and $\mathrm{JA} 135^{\top}$ are $\mathrm{AM} 282560$ and AM283537, respectively.

Phase contrast images and transmission electron micrographs of cells of strains $\mathrm{JA} 131^{\top}$ and $\mathrm{JA} 135^{\top}$ and plots of the absorption spectra of extracted pigments from the two strains are available with the online version of this paper. culture containing $2 \% \mathrm{NaCl}$ and strain $\mathrm{JA} 135^{\mathrm{T}}$ was isolated from an enrichment containing $8 \% \mathrm{NaCl}$. Subsequent culturing, purification and characterization were performed in Biebl \& Pfennig (1981) medium with the following modifications $\left(\mathrm{l}^{-1}\right) ; 1 \mathrm{~g} \mathrm{MgSO}_{4} \cdot 7 \mathrm{H}_{2} \mathrm{O}, 0.15 \mathrm{~g}$ $\mathrm{CaCl}_{2} \cdot 2 \mathrm{H}_{2} \mathrm{O}$ and $20 \mathrm{~g} \mathrm{NaCl}$ supplemented with $\mathrm{Na}_{2} \mathrm{~S}_{2} \mathrm{O}_{3} \cdot 5 \mathrm{H}_{2} \mathrm{O}(2 \mathrm{mM})$. Strain purification and a taxonomic study based on a polyphasic approach were carried out as described earlier (Srinivas et al., 2007).

Cell material for 16S rRNA gene sequencing was taken from 1-2 ml well-grown liquid culture. DNA was extracted and purified by using the Qiagen genomic DNA extraction kit. PCR amplification and 16S rRNA gene sequencing were performed as described previously (Imhoff et al., 1998b). Recombinant Taq polymerase was used for PCR. The PCR was started with the primers 5'-GTTTGATCCTGGCTCAG-3' and 5' -TACCTTGTTACGACTTCA-3' (positions 11-27 and 1489-1506, respectively, according to the Escherichia coli 16S rRNA numbering system of the International Union of Biochemistry). Sequences were obtained by cycle sequencing with the SequiTherm sequencing kit (Biozym) and the chain termination reaction (Sanger et al., 1977) using an automated laser fluorescence sequencer (Pharmacia). Sequences were aligned using the CLUSTAL_X program (Thompson et al., 1997) and the alignment was corrected manually. The CLUSTAL_X alignment file was used as the input file to the 
SEQBOOT program in the PHYLIP package (Felsenstein, 1989) and the output file from SEQBOOT was used as the input file for maximum-likelihood analysis with 100 datasets and five times jumbling. One single tree was produced using 100 trees generated during maximumlikelihood analysis using the CONSENSE program. A final dendrogram with evolutionary distances was constructed by taking the alignment.phy file as the infile and the consensus tree as the intree in the maximum-likelihood program of the PHYLIP package

While cells of strain $\mathrm{JA} 131^{\mathrm{T}}$ are vibrioid, $0.5-0.9 \mu \mathrm{m}$ wide and 2-6 $\mu \mathrm{m}$ long (see Supplementary Fig. S1a in IJSEM Online), cells of strain $\mathrm{JA}_{135} 5^{\mathrm{T}}$ are vibrioid to crescentshaped (short to very long spirals of $12-30 \mu \mathrm{m}$ occur rarely), $\quad 0.8-1.0 \mu \mathrm{m}$ wide and $3-8 \mu \mathrm{m}$ long (see Supplementary Fig S1b in IJSEM Online). Both strains multiply by binary fission. Strain JA131 ${ }^{\mathrm{T}}$ is non-motile. Strain JA135 $5^{\mathrm{T}}$ is motile by means of a pair of monopolar flagella (see Supplementary Fig. S2 available with the online version of this paper). Transmission electron micrographs of ultrathin sections of both novel strains revealed a vesicular type of internal membrane structure (see Supplementary Fig. S3a, b in IJSEM Online). Both strains were able to grow photoorganoheterotrophically [anaerobic, light $(2400 \mathrm{~lx})$, with pyruvic acid $(0.3 \% \mathrm{w} / \mathrm{v})]$. Chemoorganoheterotrophic [aerobic, dark and pyruvate $(0.3 \% \mathrm{w} / \mathrm{v})$ ] growth was observed in both strains, however, the biomass yields were poor. Photolithoautotrophy [anaerobic, light $(2400 \mathrm{~lx}), \mathrm{Na}_{2} \mathrm{~S} .9 \mathrm{H}_{2} \mathrm{O}, \mathrm{Na}_{2} \mathrm{~S}_{2} \mathrm{O}_{3} \cdot 5 \mathrm{H}_{2} \mathrm{O}$ $(0.5 \mathrm{mM})$ and $\left.\mathrm{NaHCO}_{3}(0.1 \% \mathrm{w} / \mathrm{v})\right]$, chemolithoautotrophy [aerobic, dark, $\mathrm{Na}_{2} \mathrm{~S}_{2} \mathrm{O}_{3} \cdot 5 \mathrm{H}_{2} \mathrm{O}(0.5 \mathrm{mM})$ and $\left.\mathrm{NaHCO}_{3}(0.1 \% \mathrm{w} / \mathrm{v})\right]$ and fermentative growth (anaerobic, dark, with pyruvate $[0.3 \% \mathrm{w} / \mathrm{v}]$ ) could not be demonstrated. Organic substrates utilized/not utilized by the novel strains are given in Table 1. Both novel strains could utilize ammonium chloride, glutamate and glutamine as nitrogen sources, while urea, nitrate and nitrite did not support growth. Diazotrophic growth and acetylene reduction could not be demonstrated. Niacin, thiamine and $p$-aminobenzoic acid are required as growth factors. Sulfate assimilation is absent and sulfide, thiosulphate and thioglycolate are used as sulfur sources by both novel strains; in addition, strain $\mathrm{JA}_{135^{\mathrm{T}}}$ could utilize elemental sulfur. Salt $(\mathrm{NaCl})$ is essential for the growth of both novel strains; the salinity range was from $1-5 \%(\mathrm{w} / \mathrm{v})$ and the optimum level was $2 \%(\mathrm{w} / \mathrm{v})$ for strain JA $131^{\mathrm{T}}$ and $1-3 \%$ $(\mathrm{w} / \mathrm{v})$ for strain $\mathrm{JA} 135^{\mathrm{T}}$. The $\mathrm{pH}$ range for growth of strain $\mathrm{JA} 131^{\mathrm{T}}$ is $6.5-8.0$, with an optimum at $\mathrm{pH}$ 7.0. For strain $\mathrm{JA} 35^{\mathrm{T}}$, the $\mathrm{pH}$ range for growth is 7.0-8.0, with an optimum at $\mathrm{pH}$ 7.5. The temperature range for growth for both strains is $25-35{ }^{\circ} \mathrm{C}$ and the optimum is $30{ }^{\circ} \mathrm{C}$.

Cell suspensions of both novel strains were red-brown when grown photosynthetically. The whole cell absorption spectrum of strain $\mathrm{JA} 131^{\mathrm{T}}$ showed absorption maxima at $371,473,503,540,590,803,847$ and $900 \mathrm{~nm}$ and strain $\mathrm{JA} 135^{\mathrm{T}}$ showed maxima at $377,473,503,540,590,803$ and $857 \mathrm{~nm}$, confirming the presence of bacteriochlorophyll $a$ and most probably carotenoids of the spirilloxanthin series (rhodovibrine) (see Supplementary Fig. S4a, b in IJSEM Online). An unusual shoulder peak at $\sim 909 \mathrm{~nm}$ was observed with strain JA131 ${ }^{\mathrm{T}}$ as previously observed with 'Roseospira thiosulfatophila' (Guyoneaud et al., 2002).

The DNA G + C contents of strains JA131 ${ }^{\mathrm{T}}$ and JA135 ${ }^{\mathrm{T}}$ were 67 and $71 \mathrm{~mol} \%$ (by HPLC), respectively. The phylogenetic relationships of strains $\mathrm{JA} 131^{\mathrm{T}}$ and $\mathrm{JA} 135^{\mathrm{T}}$ to other purple nonsulfur bacteria were examined using $16 \mathrm{~S}$ rRNA gene sequences. The data obtained revealed that the novel isolates clustered with the type strains of species of the genus Roseospira but were distinct from other genera of purple nonsulfur bacteria. Strains JA131 ${ }^{\mathrm{T}}$ and JA135 showed the highest gene sequence similarities to the type strains of Roseospira navarrensis (95.9\%), Roseospira marina (95.5\%), Roseospira mediosalina (94.2\%) and 'Roseospira thiosulfatophila' (96.1\%). The sequence similarity between strains $\mathrm{JA} 131^{\mathrm{T}}$ and $\mathrm{JA} 135^{\mathrm{T}}$ is $96.6 \%$ (Fig. 1). Apart from differences in $16 \mathrm{~S}$ rRNA gene sequences, strains $\mathrm{JA} 131^{\mathrm{T}}$ and $\mathrm{JA} 135^{\mathrm{T}}$ also showed clear phenotypic differences to other species of the genus Roseospira (Table 1) that justify their description as representatives of two separate novel species, Roseospira visakhapatnamensis sp. nov. and Roseospira goensis sp. nov., respectively.

\section{Description of Roseospira visakhapatnamensis sp. nov.}

Roseospira visakhapatnamensis (vi.sa'kha.pat.nam.en.sis. N.L. fem. adj. visakhapatnamensis pertaining to Visakhapatnam, a port city in Andhra Pradesh, India, from where the type strain was isolated).

Cells are vibrioid, $0.5-0.9 \mu \mathrm{m}$ wide and 2-6 $\mu \mathrm{m}$ long. Cells are non-motile and divide by binary fission. Growth occurs under anaerobic conditions in the light (photoorganoheterotrophy) or under aerobic conditions in the dark (chemoorganoheterotrophy). Internal photosynthetic membranes are of the vesicular type. Phototrophic cultures are red-brown. The in vivo absorption spectrum of intact cells in sucrose exhibits maxima at $371,473,503,540$, $590,803,847$ and $900 \mathrm{~nm}$, confirming the presence of bacteriochlorophyll $a$, with an unusual absorption shoulder at $900 \mathrm{~nm}$. The type strain is mesophilic $\left(30^{\circ} \mathrm{C}\right)$, with a $\mathrm{pH}$ optimum of 7.0 and requires $2 \% \mathrm{NaCl}(\mathrm{w} / \mathrm{v})$ for optimal growth. The preferred mode of growth is photoorganoheterotrophy with a few organic compounds. Pyruvate, aspartate and peptone are good carbon sources. Growth also occurs on mannitol and cysteine. Photoautotrophic and chemoautotrophic growth are not possible in the presence of sulfide/thiosulfate/hydrogen as electron donors and $\mathrm{NaHCO}_{3}$ as the carbon source. Fermentative growth is not possible in the presence of pyruvate as a fermentable carbon source. Sulphate assimilation is absent. Sulfide, thiosulfate and thioglycolate are used as sulfur sources. Niacin, $p$-aminobenzoic acid and thiamine are required as growth factors. The DNA $\mathrm{G}+\mathrm{C}$ base composition is $67 \mathrm{~mol} \%$ (by HPLC). Natural habitat is marine waters. 


\section{Table 1. Differentiating characteristics of species of the genus Roseospira}

Taxa: 1, Roseospira marina; 2, Roseospira navarrensis; 3, 'Roseospira thiosulfatophila'; 4, Roseospira mediosalina (Kompantseva and Gorlenko, 1984); 5 , strain JA131 ${ }^{\mathrm{T}} ; 6$, strain JA135 ${ }^{\mathrm{T}}$. Data for taxa 1-3 are from Guyoneaud et al. (2002). +, Substrate utilized or present; -, substrate not utilized or absent; $(+)$, weak growth; $\mu$, growth under micro-oxic conditions; ND, not determined. Pyruvate was utilized by all the strains. Caproate, caprylate, glycolate, tartrate, methionine, ethanol and propanol were not utilized by any of the strains.

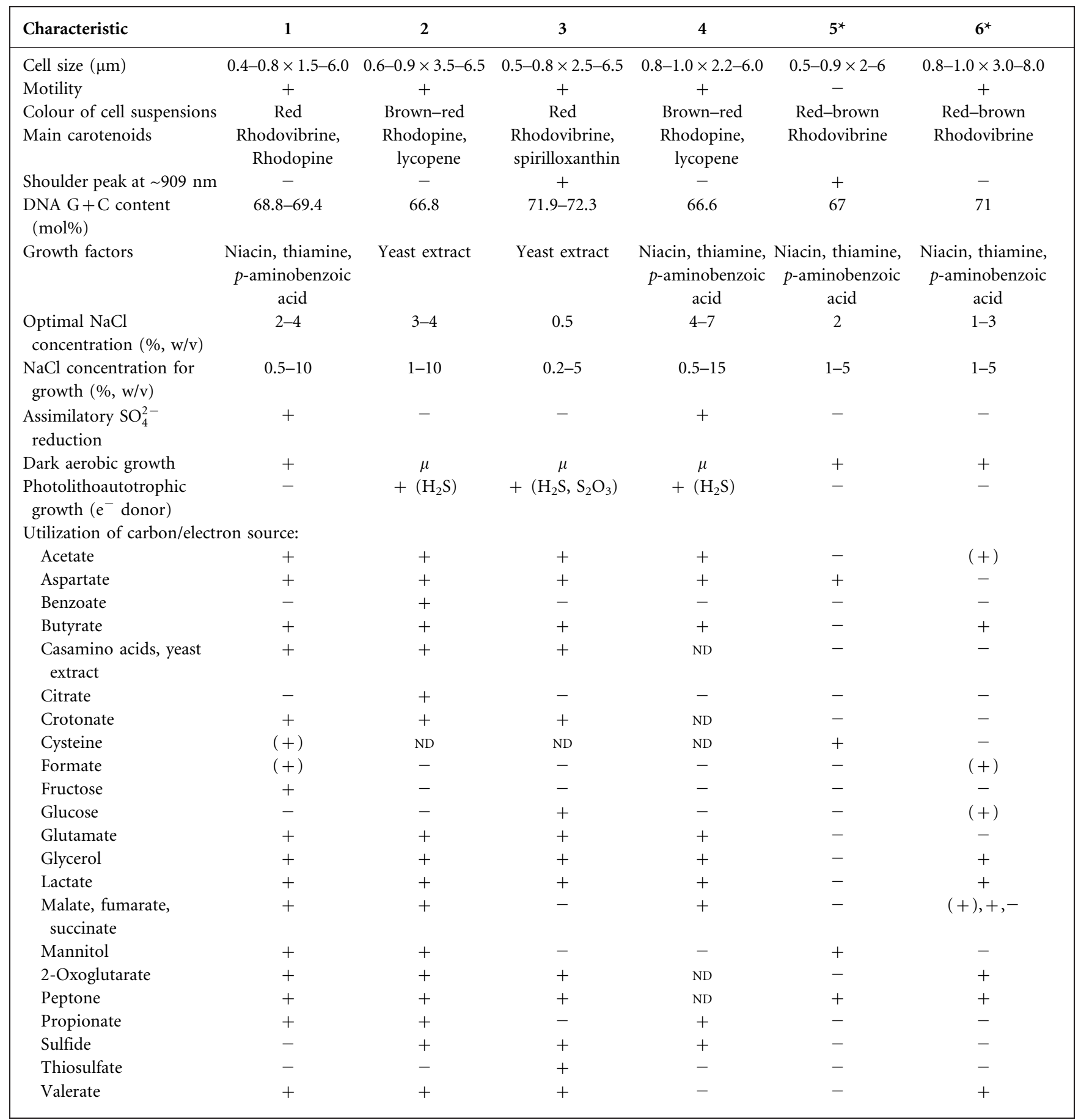

${ }^{\star}$ Organic substrate utilization was tested during photoheterotrophic growth. 


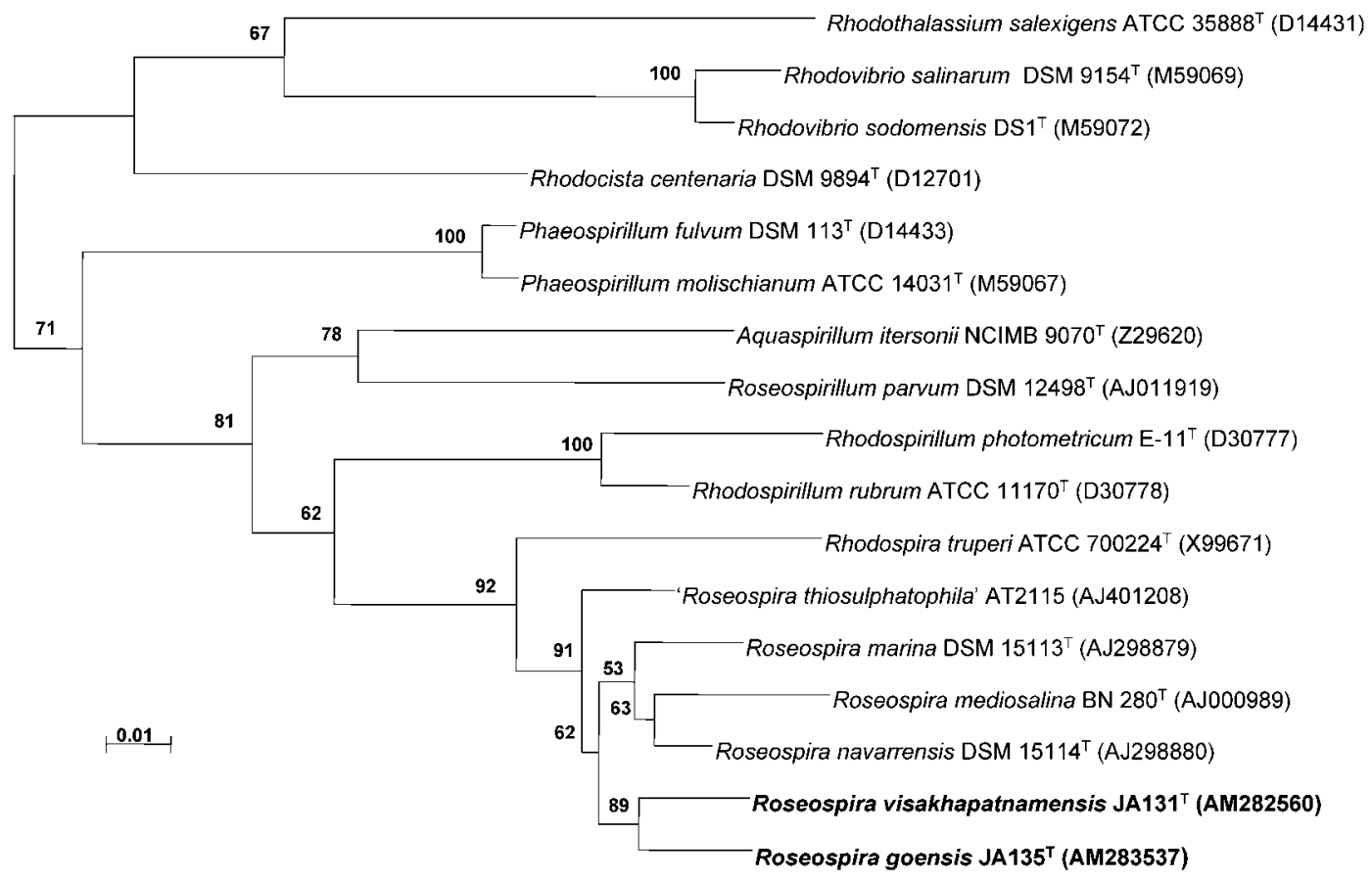

Fig. 1. Dendrogram constructed using the maximum-likelihood method depicting the phylogenetic relationships of strains $\mathrm{JA} 131^{\top}$ and $\mathrm{JA} 135^{\top}$ within the family Rhodospirillaceae determined using $16 \mathrm{~S}$ rRNA gene sequence analysis. Bar, 1 nucleotide substitution per 100 nucleotides.

The type strain, strain JA131 ${ }^{\mathrm{T}}\left(=\mathrm{ATCC}\right.$ BAA- $1365^{\mathrm{T}}=\mathrm{JCM}$ $14190^{\mathrm{T}}$ ), was isolated from water samples from a fishing harbour at Visakhapatnam, a city which faces into the Bay of Bengal and is on the East coast of India.

\section{Description of Roseospira goensis sp. nov.}

Roseospira goensis (go'en.sis. N.L. fem. adj. goensis pertaining to Goa, a state in India known for its beautiful beaches, from where the type strain was isolated).

Cells are vibrioid to crescent-shaped, $0.8-1.0 \mu \mathrm{m}$ wide and $3.0-8.0 \mu \mathrm{m}$ long. Cells are motile by means of a pair of monopolar flagella and divide by binary fission. Growth occurs under anaerobic conditions in the light (photoorganoheterotrophy) or under aerobic conditions in the dark (chemoorganoheterotrophy). Internal photosynthetic membranes are of the vesicular type. Phototrophic cultures are red-brown. The in vivo absorption spectrum of intact cells in sucrose exhibits maxima at $377,473,503,540,590$, 803 and $857 \mathrm{~nm}$ confirming the presence of bacteriochlorophyll $a$ and most probably rhodovibrine. The type strain is mesophilic $\left(30{ }^{\circ} \mathrm{C}\right)$, with a $\mathrm{pH}$ optimum at 7.5 and requires $1-3 \% \mathrm{NaCl}(\mathrm{w} / \mathrm{v})$ for optimal growth. The preferred mode of growth is photoorganoheterotrophy with a few organic compounds. Butyrate, valerate, lactate, pyruvate, fumarate, glutarate, glycerol, 2-oxoglutarate and peptone are good carbon sources. Growth also occurs on formate, acetate, malate and glucose. Photoautotrophic and chemoautotrophic growth does not take place in the presence of sulfide/thiosulfate/hydrogen as the electron donor and $\mathrm{NaHCO}_{3}$ as the carbon source. Fermentative growth does not take place in the presence of pyruvate as the fermentable carbon source. Sulphate assimilation is absent. Sulfide, thiosulphate, thioglycolate and elemental sulfur are used as sulfur sources. Niacin, thiamine and $p$ aminobenzoic acid are required as growth factors. The DNA G $+\mathrm{C}$ content is $71 \mathrm{~mol} \%$ (by HPLC). Natural habitats are marine salterns.

The type strain, $\mathrm{JA} 135^{\mathrm{T}} \quad\left(=\mathrm{ATCC} \quad \mathrm{BAA}-1364^{\mathrm{T}}=\mathrm{JCM}\right.$ $14191^{\mathrm{T}}$ ) was isolated from sediment samples from a marine saltern, Goa, facing the Arabian sea on the West coast of India.

\section{Acknowledgements}

Financial assistance received from Department of Biotechnology and Department of Ocean Development, Government of India is acknowledged. A.P. and T.N.R.S. acknowledge the CSIR, Government of India, for the award of SR fellowships.

\section{References}

Biebl, H. \& Pfennig, N. (1981). Isolation of members of the family Rhodospirillaceae. In The Prokaryotes, pp. 167-273. Edited by M. P. Starr, H. Stolp, H. G. Trüper, A. Balows \& H. G. Schlegel. New York: Springer. 
Felsenstein, J. (1989). PHYLIP (phylogenetic inference package) version 3.5.1. Distributed by the author. Department of Genome Sciences, University of Washington, Seattle, USA.

Guyoneaud, R., Sophie, M., Eatock, C., Bothorel, V., Hirschler-Réa, A., Willison, J., Robert, D., Liesack, W., Herbert, R. \& other authors (2002). Characterization of three spiral-shaped purple non-sulfur bacteria isolated from coastal lagoon sediments, saline sulfur springs, and microbial mats: emended description of the genus Roseospira and description of Roseospira marina sp. nov., Roseospira navarrensis sp. nov., and Roseospira thiosulfatophila sp. nov. Arch Microbiol 178, 315-324.

Imhoff, J. F., Süling, J. \& Petri, R. (1998a). Reclassification of species of the spiral-shaped phototrophic purple non-sulfur bacteria of the $\alpha$ Proteobacteria: description of the new genera Phaeospirillum gen. nov., Rhodovibrio gen. nov., Rhodothalassium gen. nov. and Roseospira gen. nov. as well as transfer of Rhodospirillum fulvum to Phaeospirillum fulvum comb. nov., of Rhodospirillum molischianum to Phaeospirillum molischianum comb. nov., of Rhodospirillum salinarum to Rhodovibrio salinarum comb. nov., of Rhodospirillum sodomense to Rhodovibrio sodomensis comb. nov., of Rhodospirillum salexigens to Rhodothalassium salexigens comb. nov. and of Rhodospirillum mediosalinum to Roseospira mediosalina comb. nov. Int J Syst Bacteriol 48, 793-798.

Imhoff, J. F., Süling, J. \& Petri, R. (1998b). Phylogenetic relationships among the Chromatiaceae, their taxonomic reclassification and description of the new genera Allochromatium, Halochromatium, Isochromatium, Marichromatium, Thiococcus, Thiohalocapsa and Thermochromatium. Int J Syst Bacteriol 48, 1129-1143.

Kompantseva, E. I. \& Gorlenko, V. M. (1984). A new species of moderately halophilic purple bacterium Rhodospirillum mediosalinum sp. nov. Mikrobiologiia 53, 954-961 (in Russian).

Sanger, F., Nicklen, S. \& Coulson, A. R. (1977). DNA sequencing with chain terminating inhibitors. Proc Natl Acad Sci U S A 74, 5463-5467.

Srinivas, T. N. R., Anil Kumar, P., Sasikala, Ch. \& Ramana, Ch. V. (2007). Rhodovulum imhoffii sp. nov. Int J Syst Evol Microbiol 57, 228-232.

Thompson, J. D., Gibson, T. J., Plewniak, F., Jeanmougin, F. \& Higgins, D. G. (1997). The CLUSTAL_X windows interface: flexible strategies for multiple sequence alignment aided by quality analysis tools. Nucleic Acids Res 25, 4876-4882. 